\title{
ARTICLE 7 PROCESS AND DEMOCRATIC BACKSLIDING OF HUNGARY AND POLAND. DEMOCRACY AND THE RULE OF LAW
}

\author{
Lukasz ZAMECKI, PhD
}

Faculty of Political Science and International Studies, University of Warsaw, Poland lzamecki@uw.edu.pl

Viktor GLIED, PhD

Faculty of Humanities, University of Pécs, Hungary

glied.viktor@pte.hu

\begin{abstract}
This paper examines developments in Poland following the 2015 elections and in Hungary since 2010, which included the gradual destruction of democratic institutions, challenges to the rule of law, as well as to the system of checks and balances. The authors consider the Ziblatt-Levitsky model (2018) as a meaningful framework for the analysis of the way in which the power structure was reshaped and have based their research on the classification set out in this model. Our objective is to present the political changes that took place in the two Central-Eastern-European countries during the last decade that resulted in the process under Article 7 being used for the first time in the history of the EU. The paper conclusion is that the path of de-democratization of Hungary and Poland is seen from the perspective of the EU and Council of Europe, as similar one. In actions taken toward both countries, the EU concerns mostly the principle of the rule of law.
\end{abstract}

Keywords liberal democracy, democratic backsliding, Article 7, European Union.

\section{Introduction}

Liberal democracy essentially represents a value choice based on the synthesis of classical liberal values and the principle of the rule of law. It is a legal technique, a framework, an attitude, an approach, and a political value as well (Dahlberg et al. 2015). As democracy is fragile by its nature, it is always in danger of the development of authoritarian tendencies that can ultimately crystalize within the system. Such a situation can arise as the result of a legitimate response to an economic and/or political crisis, which very quickly places question marks on certain elements of the rule of law. We tend to think of Western-style democracy as the most progressive type of regime that satisfies the principles and moral foundations of democracy, i.e. ensures liberty and 
equality, as well as the possibility of the pursuit of happiness (Szücs 2018). However, history shows us a number of examples where liberal democratic systems have been unable to provide effective responses to challenges to itself or to guarantee the security of its citizens. A shadow of doubt is thus cast over its claim to legitimacy.

There is considerable literature on democratic backsliding and it indicates that some of the main reasons for democratic erosion are:

- $\quad$ populist-authoritarian forces (i.a. Inglehart and Norris 2019);

- threats to "human security" (terrorist attacks, crime, climate changes, natural environment destruction, mass migrations, etc.);

- use of the media to control information (echo chambers, polarization, disinformation);

- $\quad$ economic inequality and relative deprivation (i.a. Acemoglu and Robinson 2006).

Studies show that political actors begin to question the democratic set-up and to promote an alternative way of thinking for a number of reasons, which include: the fear, prevalent in transitioning societies, of being left behind in the race for progress; tensions arising from social differences and injustice; as well as the existence of different paths to economic development and their social consequences. Frustration is generated at all levels-individual, community, and government - which then manifests as an all-round erosion of faith in democracy (Justino and Martorano 2016; Griffin and de Jonge 2014). Politically active people seemingly respect fundamental democratic values, however in the cases many of them question traditional attitudes and norms claiming that a crisis situation has emerged and finally that effective action must be taken to resolve it (Levitsky and Way 2010). They then create a provisional, hybrid system which systematically damages the democratic framework and distorts political competition in their favour (Bozóki and Hegedüs 2018). During the last 5-10 years this process has reached an advanced stage and has inevitably resulted in the gradual establishment, both in Hungary and in Poland, of a very powerful state that may be described as a form of the 'illiberal democracy' (Zakaria 1997).

The focus of this paper is on developments observed in Poland after the 2015 elections and in Hungary since 2010, when the second Viktor Orbán government came to power and brought about the gradual destruction of democratic institutions, presented challenges to the rule of law 
and to the system of checks and balances among the different branches of the government. In our view the Ziblatt-Levitsky model (2018) is a meaningful framework for the analysis of the way in which the power structure was reshaped in these countries; our research is based on the classification set out in this model. Significantly, the first two cases initiated under Article 7 of the European Union Treaty, which aims to provide a mechanism for the assessment and sanctioning of member states in violation basic values of the European Union, were against Poland and Hungary (European Commission, 2017c).

Article 7 is in particular focus now because the discourse on the procedure stipulated under it and the debate on the budget for the new EU financial period of 2021-2027 are happening simultaneously. The European Union-which plays a major role in ensuring the democratic functioning of member states - is currently unable, or perhaps unwilling to take effective measures in the Hungarian and Polish cases. The EU procedures also do not allow public disclosure of all aspects of the erosion of democratic norms in Hungary and Poland. However, from information available developments seem to be very similar in the two countries. Our objective has been to examine the political changes that occurred during the period under study in these two countries.

A good amount of research on recent changes in the Polish and Hungarian political systems have been conducted (e.g. Bruszt 2015; Przybylski 2018; Sadurski 2018). We propose to concentrate on differences as well as similarities in democratic backsliding there as discernible from the arguments of the EU and Council of Europe. The aim is to compare the allegations related to the two countries and to carry out an assessment from the point of view of democracy theory. Main research questions concerns two issues: what are the similarities of the process of dedemocratization of Poland and Hungary resulting from EU documents in the course of the Article 7 process and which aspects of the functioning of democracy are particularly monitored under the Article 7 procedure.

\section{Justifications for undermining the rule of law}

Decision-makers justify efforts to undermine the rule of law with the argument that an efficient (powerful) government must react to social demands (fair) and challenges swiftly (responsible) and that such a reaction is as important as protecting basic liberal values. But such political actors also claim that the importance of adhering to rules and norms in certain situations may be questioned, or that frameworks may be realigned to fulfil the demands of the government 
and those in power, which is even more in their own interest. Such contestations have also been observed in Hungary and Poland (Bruszt 2015; Przybylski 2018; Sadurski 2018). Consciously blurring the line between branches of government, questioning the independence of the judiciary, putting courts under political pressure, increasing the pliability of the civil service, and using the media for partisan and pro-government interests are not entirely new phenomena in the period following the transition to democracy (Rupnik 2016).

Thus government attempts to narrow down democracy are lawful in the sense that they are approved by the legislature; unsurprisingly they are also justified as attempts to improve democracy itself. According to Ziblatt and Levitsky there is cause for concern if a party and/or a politician:

1. Denies or doubts democratic norms and rules;

2. Denies the legitimacy of political rivals;

3. Tolerates or encourages violence;

4. Restricts the rights of political opponents and the liberty of the press.

These conditions are present in the political life of both countries, at times in obvious ways, in others less openly. However, it must also be noted that the reaction of the European Union has been different to the Hungarian and the Polish case. The reason is that the two countries pursued a 'push and release' political approach, exploiting the slow decision-making and political divisions within the European Union, effectively blocking direct confrontation (Meijers and van der Veer 2019). At the same time many similarities in the process of the backsliding of democracy (Drinóczi and Bień-Kacała 2018) can be seen.

The path taken by Viktor Orbán's cabinet in Hungary since 2010 has been systematically adopted by the PiS (Law and Justice) party led by Jarosław Kaczyński in Poland since 2015. It was the openly acknowledged intention of the PiS to "turn Warsaw into Budapest by the Vistula River" (Karolewski 2019). Both politicians were active members of the roundtable talks on the regime change in 1989. They both argued that the transitions to democracy should be finalised, the mistakes of the political elite rectified, and the power to make decisions given back to the people (Csehi and Zgut 2020). They have a very similar ideological background and both pursue a nationalist/conservative agenda. Their 'new compromise', aimed at radically reshaping the political framework and readjusting the boundaries of democracy can thus be understood as a logical outcome of this base. 
According to their approach, right-wing, community-based powers can represent national interests, protect the country and its citizens, and also rebuild the trust destroyed by left-wing liberals. Their rhetoric is very sharp against the left regularly described as a "traitor" that "sells out the country and serves foreign interests". The two politicians also resemble each other in terms of the strongly populist, rabble-rousing, Eurosceptic, re-nationalising, propagandistic, centralising set of policies and political efforts that they espouse, while consciously building their own sphere of economic interest by rapidly expanding the new national capitalist class (Palonen 2018).

\section{Procedure under Article 7 of the EU Treaty}

Article 7 of the Treaty on European Union (TEU) sets out a procedure that authorizes the European Council to suspend certain rights of a member state, in case it is found to be in violation of the principles of democratic governance set out in Article 2. The idea was first introduced into European Law by the Treaty of Amsterdam because of the lack of a mechanism that could deal with states that acted against the values such as the rule of law and respect for personal freedoms, and could thus be a risk to European stability. The late introduction of such an 'early-warning' mechanism to European Law needs to be seen in the context of the changing circumstances of European integration.

When the European Community was established in the 1950's the priority of the time was recovery and reconstruction and so the idea of excluding members and the need for creating a mechanism for the purpose did not draw much attention. However, over time the focus of the Community began to widen and became increasingly political. After the regime changes the Community welcomed the newly democratized Central and Eastern European countries, as well as new political challenges arising in existing political systems, ultimately led to the formulation of Article 7 of the Treaty on European Union (TEU). Article 7(1) states that:

On a reasoned proposal by one third of the Member States, by the European Parliament or by the European Commission, the Council, acting by a majority of four fifths of its members after obtaining the consent of the European Parliament, may determine that there is a clear risk of a serious breach by a Member State of the values referred to in Article 2. Before making such a determination, the Council shall hear the Member State in question and may address recommendations to it, acting in accordance with the same procedure. The Council shall regularly verify that the grounds on which such a determination was made continue to apply. 
The step envisaged in Article 7 is taken when the situation is already alarming, but it can still be seen as a preventive and monitoring mechanism. What is significant is that the EU decided to protect the values of human dignity, freedom, democracy, equality, the rule of law, respect for human rights, pluralism, non-discrimination, tolerance, justice, solidarity and equality between women and men referred to in Article 2 of the TEU as an integral part of the European political culture and identity.

Action under Article 7 is, however, seen as a 'nuclear option', and from the political point of view is difficult to implement. In order to strengthen the Rule of Law, the European Commission proposed a new EU Framework in 2014, which sought to 'fill a gap' between the threat to the rule of law and the mechanism under Article 7 of the TEU. The rule of law, understood as a 'legality; legal certainty; prohibition of arbitrariness of the executive powers; independent and impartial courts; effective judicial review including respect for fundamental rights; and equality before the law', become 'the vehicle for ensuring compliance with and respect for democracy and human rights' (European Commission 2014).

In 2017 the European Council determined that a clear risk of a serious breach of the values referred to in article 2 of the TEU existed in Poland, which became the first country to be subjected to the procedure under Article 7. A similar determination was reached respect of Hungary in 2018.

\section{Hungary ${ }^{1}$}

Central and Eastern Europe, including Hungary in the last three decades was an ideal place to learn the ways of democracy and establishing respect for the rule of law, are both long-term and challenging processes. In many cases, the rule of law principle is suspended when the state has been successful in implementing a basic institutional structure and in establishing a system of checks and balances.

Yet, citizens, especially the political elite go on believing that it is sufficient that this framework exists. In former Communist countries, reforms implemented during the transition to democracy led to private and political liberties being protected by the legal system and becoming

\footnotetext{
1 This research project was supported by the European Union. EFOP-3.6.3-VEKOP-16-2017-00007, Young researchers from talented studentsFostering scientific careers in higher education.
} 
generally accepted norms, so much so that no further struggles were considered necessary to protect them. Democracy becoming a 'cliché', a form without substance. Gradually, public perceptions and priorities began to change, leading to increased vocalization about the lack of an actual 'transition to good living standards' and dissatisfaction with low wages (Bíró and Nagy 2017).

This observation is also supported by value surveys created after the regime change at the beginning of the 1990s which identified attitudes crystalized by the distorted Hungarian employment structure, under which $60 \%$ of the adult population was either directly employed by the state or a significant proportion of wages were based on government redistribution mechanisms (Mihályi 2014, pp. 902-903). For this reason, a significant share of the Hungarian population in the transition period believed in paternalistic redistribution policies, and immediately turned to political reactions whenever such 'acquired' rights and benefits were felt to be in danger. The majority of Hungarians strongly protested austerity measures following the transition to democracy, just as they did radical modernization reforms after 2004 (Tölgyessy 2017).

\section{"Extra governance" with a two-third majority}

In Hungary, a crisis had already commenced in the summer of 2006 and went on to become even more severe. The public was surprised to discover that growth in the previous years was mostly funded on credit. The increasingly negative public perception hit rock bottom when a secret speech by Ferenc Gyurcsány, the socialist prime minister, acknowledging that the cabinet had lied to voters about the state of the country, was leaked. The almost immediate result was street riots throughout the country, including in Budapest (starting on 17 September 2006, the day of the leak.). The biggest opposition party, the right-wing/nationalist Fidesz (Alliance of Young Democrats) used this opportunity to keep the left-wing coalition under fire. With its encouragement protests continued till the 2010 national elections. Reform attempts by the government mostly failed and it continued to lose support. With increasing corruption and regular scandals, political problems deepened into a long-term crisis of morality and ethics.

The effects of the global financial and economic crisis of 2008 reached Hungary at this time, producing more shocks for the already shrinking economy. Unemployment rates rose sharply, tariffs of public utility services, and the value of instalments of loans based in foreign currencies skyrocketed. Finally, at the end of spring 2008, as the alliance fell apart, the coalition 
government was dissolved. At that stage there was no doubt that for the largest opposition bloc, comprising Fidesz and its Christian-democrat partners, the time to rule had arrived. As a straight consequence the right-wing coalition won the 2010 elections with a two-thirds majority and then again in 2014 and 2018, thus their goals acquired the sheen of a democratic mandate (Zakaria 1997). The fledgling two-party system was disbanded, the left-wing socialist and liberal bloc having fallen apart. Fidesz was able to start introducing changes in the economic and social subsystems without any effective opposition (Glied 2014). A new era of Hungarian politics had begun, labelled by the new government as a revolutionary transformation ('revolution in the voting booth'). System-level transformations impact personal livelihoods, economic hinterlands of the political sides, the intelligentsia and turned social groups, professions and generations against each other, further straining the relationship of Hungary and the European Union, which was made worse by the migrant crisis commencing in 2015.

Benefiting from this advantage, the System of National Cooperation (NER) has been implemented as an opportunity for and an expectation of those who live, work, and do business in Hungary (Schmidt 2018). After the 2010 victory Orbán began working to replace the temporary framework for government, established during the transition to democracy. The announcement of the System of National Cooperation, and the entry into force of the new fundamental law on 1 January 2012, were important steps in this process The fundamental law described Hungary as an independent, democratic country observing the rule of law, in which the state operates on the principle of power sharing; it also declared that public authorities control each other. According to O'Donnell (1998) where the constitutional legal order prevails and there is accountability for decisions, then the system of checks and balances can be said to be operable.

On the contrary, Dobson (2012) contends that democratic institutional frameworks can become hollow, when they are apparently functional, but are actually only decorative elements on the ruins of democracy. Orbán has from the earliest stages actively curtailed the system of checks and balances. He has been able to do so as he won and then retained a two-thirds majority in parliament, allowing his government to act as it willed. However on the surface the rule of law continues to operate, and different political actors, including the judiciary remain functional.

In the summer of 2014 (at Bálványos Summer School in Transylvania, Romania), Orbán openly declared that that Europe had seen the end of an era, the neo-liberal period that had followed the fall of Soviet domination [...], and that Hungary had to move away from liberal democracy. 
Efforts to create and protect a unified nation would no longer be hindered by the overly individualist and pointless foundations of liberal democracy, illiberal politics based on nationalist pillars would prevail (Koroncai 2014). Orbán said that the new system outlined new norms, ideas and ideological constructions, which were based on and in accord with reality (Juhász, László, and Zgut 2015). The 'national interest' would enjoy absolute priority over anything else. The focus of government would be on rebuilding the nation.

Since the beginning of Orbán's rule, Hungary has witnessed many examples of the weakening of constitutional institutions. The powers of the Constitutional Court have been curtailed and the process for the appointment of judges altered at multiple stages. Since 2015 in certain kinds of cases the courts have not dared to, or have been unwilling to make decisions that would be obvious if legal and constitutional principles were kept in mind. A concrete example of this conduct is the application of certain deferral tactics in the lex $C E U^{2}$ case, which had never been used in other procedures, even though they were lawful (Jakab 2018). With a two-third majority in parliament and an extremely weak opposition, there has been no possibility of internal political checks. The only obstacles in the way of the legislative majority have been European institutions and international pressure (mostly US and German) (Kelemen 2017).

A number of changes have been made in the judicial administrative system. The number of jurors was raised from 11 to 15 and their term extended from 9 years to 12 . The term of the general attorney was increased from 6 years to 9. Following the election of (former Fidesz member) Péter Polt as the general attorney, his office rejected 300\% more complaints of official corruption than in the period from 2006 to $2010 .^{3}$ The government reduced the number of ombudsmen from four to one, and simply closed the office of the Commissioner for Data Protection. The National Law Enforcement Council was replaced by the National Office for the Judiciary $(\mathrm{OBH})$ which was conferred with vast powers on a number of matters, including the total number of judges and the rules in respect of their appointment. However, this change was only partially implemented because of severe criticism from the European Commission.

\footnotetext{
2 The Lex CEU introduced various measures to control the functioning of Higher Education Institutions, the aim being to make the operation of the Central European University in Hungary impossible.

3 See: Polt Péter kinevezése óta meredeken zuhan a politikai korrupciós ügyekben indított eljárások száma. 2015. február 6. http://atlatszo.hu/2015/02/06/polt-peter-kinevezese-ota-meredeken-zuhan-a-politikai-korrupciosugyekben-inditott-buntetoeljarasokszama [accessed 29/03/2020].
} 
Only pro-government members were elected to the Media Council—whose primary aim was supposed to have been ensuring the operation of a democratic media. The same happened with the National Media and Communication Authority, which provides radio frequency licences (Sárközy 2014). The public media has witnessed extensive centralisation, the independence of media service companies (TV, radio) was terminated and a monopolistic news agency was also brought under central control.

\section{EU Criticism of the state of affairs in Hungary}

The Venice Commission (VC), an independent constitutional law advisory body of the Council of Europe has continuously criticised (Council of Europe, Venice Commission opinions and reports - CDL/CDL-AD(2011/2012/2013/2014/2015/2016/2017/2018/2019)) the state of the rule of law in Hungary since 2011, and explained in its positions what reasons it has identified. These complaints are mostly centred around the weakening of the system of checks and balances and the degree of concentration of power. The Hungarian government has introduced such changes in the planned legislation. The VC has voiced concerns regarding the following:

1. the fundamental $\mathrm{law}^{4}$, stating that it fails to ensure transparency, and also regarding each of the amendments of the constitution.

2. restriction of certain powers of the constitutional court and the transformation of the judicial system, stating that Hungary violates the right to fair procedure. (It has also stated that the unprecedented powers of the chief judge should be restricted.)

3. legislation on freedom of information, and on the attorney general's office.

4. new election law adopted in 2011.

5. new church law.

6. legislation applicable to media regulation.

7. law on national minorities.

8. lack of transparency of organisations receiving support from abroad and the "CEU Act", stating that the government did not consult stakeholders about the proposal. (Act LXXVI of 2017)

\footnotetext{
4 The Hungarian Government requested an Opinion on three legal questions arising in the process of drafting the New Constitution of Hungary CDL-AD(2011)001-e whereas the Monitoring Committee of PACE requested an Opinion on the new Constitution of Hungary CDL$\mathrm{AD}(2011) 016$-e.
} 
9. STOP Soros laws (2018), for non-compliance with international human rights laws, (they would authorise the minister of the interior to ban certain non-governmental organisations in case of national security risks.

10. special immigration tax.

11. special public administration tribunals (planned in 2019).

The attitude of the government is reflected in the fact that it has failed to even translate its position statements into Hungarian. Such documents have had to be published by nongovernmental organisations, such as the Hungarian Helsinki Committee and the Hungarian Civil Liberties Union. Opposition parties have voiced their concern that they were not invited to the state media channels, and also that they have had to face serious restrictions in respect of their parliamentary work as well as in their participation in the public discourse. In 2019 the National Audit Bureau imposed severe fines on almost each of the opposition parties, claiming that they had misused budget funding provided to parties participating in the national elections, or that they had accepted funding illegally.

\section{The migrant crisis and mandatory quotas}

Starting in the early spring of 2015 an unprecedented wave of migration reached the Balkan countries and Hungary. The flood of migrants appearing in Central Europe-and heading toward Western Europe-posed an almost unresolvable challenge to the asylum management systems at the national and also the EU levels. The Hungarian government began criticising the immigration and integration policies of the European Union, particularly in relation to economic migrants, declaring that the EU had failed at adequate regulation. In addition, the Hungarian government rejected the "obligatory relocation quota" imposed after the European Commission announced a refugee emergency, stating that European solidarity required each Member State to take part in managing the crisis by accepting refugees in their countries. ${ }^{5}$ Hungary's contention was that the migration crisis could not be resolved through relocation quotas, which would only delay any resolution. As Orbán asserted: "Westerners want to get rid of the unwisely accepted migrants by

\footnotetext{
${ }^{5}$ The six-point action plan proposed the separation of refugees and economic immigrants, creating a list of safe countries, involving Turkey and Russia in finding a solution, and the participation of the United States, Canada and some South American countries.
} 
allocating them to countries that protected themselves and had not let them in, such as Hungary." (Szabó, 2017). The issues involved were clearly extremely complex and the European public was divided. There were no clear answers forthcoming from EU headquarters in Brussels, and the entire discourse on the future of the EU was affected.

On 24 February 2016 Viktor Orbán announced that the government would hold a referendum on the obligatory relocation quota. The government narrative on the referendum had two parts. In the first Brussels and along with it the liberal European elite was blamed for the whole problem. The key themes were that the EU migration policy and multiculturalism had both failed (Referendum, 2016). The second part of the narrative was aimed at reinforcing cultural concerns about Hungarian society and encouraging the already existing negative attitudes towards the mostly Muslim migrants. The referendum on the quota was finally held on 2 October 2016. The majority of votes were cast against the quota, but in the end the outcome was found to be invalid, as less than $50 \%$ of those eligible to vote had participated. ${ }^{6}$

The Hungarian government continued the anti-quota and anti-Brussels campaign (Glied and Pap 2016; Balogh 2016; Kacziba 2020). Budapest was not alone this time, since Slovakia also announced that and took legal steps to block the implementation of the quota (Gotev 2016). A Central European group made up of the Visegrad (V4) countries and in various cases Austria, Slovenia, and Croatia (Balogh 2017) have released similar political statements regarding the migration crisis. The government of Poland, serving its own domestic political objectives, also severely criticized the EU immigration policy.

In June 2017, the European Union initiated legal action against Hungary, Poland, and the Czech Republic, after the three countries formerly rejected the implementation of the EU decision regarding the compulsory relocation of refugees (Euractiv 2017).

Finally, on 16 January 2020 the European Parliament voted to continue the Article 7 proceedings launched against Poland and Hungary. In total, 446 MEPs voted for the proposal, 178 rejected it with 41 absent. Most members of the European People's Party (EPP) also voted yes. According to the position statement, the standing of the rule of law has deteriorated in both countries, and neither member has taken meaningful steps to ensure the prevalence thereof. The

\footnotetext{
6 The number of votes required for a valid referendum was 4.1 million, while in the end 3418387 valid votes were cast (41.32\%). The share of 'no' votes was $98.36 \%$, while $1.64 \%$ voted 'yes.' The high number of invalid votes shall also be highlighted (6.17\%). http://valasztas.hu/hu/ref2016/1154/1154_0_index.html. [accessed 11/01/2017].
} 
EP requested the Council of the European Union to prepare specific recommendations to the countries, and to also give deadlines for completion. The adopted resolution also suggests that the use of EU funding in the future shall be tied to observing the rule of law (Rule of law in Poland and Hungary has worsened, 2020).

\section{Debate over the rule of law in Hungary}

The debate over the apparent decline of the rule of law in Hungary became more severe in 2017 for several reasons; the primary ones being changes in the higher-education system and the Central European University (CEU) case, the treatment of asylum-seekers, and legislation related to civil society organisations, as well as the national consultation campaign launched by the government. The criticism against the Hungarian government focused on the adoption by the national assembly of an amendment to the higher-education law, requiring all higher-education institutions operating in Hungary, but issuing foreign degrees to be teaching institutions in their parent countries also (the US, in the case of the CEU). In the end, CEU opened its new campus in Vienna and also moved its US programmes there. George Soros, the businessman who funded the $\mathrm{CEU}$, said at the inauguration: "CEU has strongly protected academic freedom from the corrupted government of Viktor Orbán, while he intended to destroy the university." (Zsolt, 2019). The prime minister denied that the government attempted to close $\mathrm{CEU}$, contending that national consultation was a democratic effort, and also that the act on civil society organisation follows the Russian and Israeli example. "We would like to reform the EU, but our European commitment is undoubted," said Viktor Orbán. Frans Timmermans, the Vice President of the European Commission insisted on launching infringement proceedings against Hungary, because of the CEU legislation, since it was incompatible with laws of the EU. He also criticised the Hungarian government for the "false accusations" against the EU included in the national consultation campaign titled "Stop Brussels / About the Soros Plan" (European Parliament, 2017). The sixth national consultation campaign (National Consultation, 2017) surveyed public opinion on six different topics.

1. Public utility tariffs;

2. Promotion of immigration;

3. Countering international organisations supporting immigration;

4. Transparency of activist groups financed from outside of the country;

5. Keeping labour policies a national issue; 
6. Keeping tax policies a national issue.

It had already been stated in the position statement of the European Parliament adopted on 17 May 2017 that the situation in Hungary justified the launching of proceedings against it which could result in sanctions being imposed. The EP statement referred to the plenary debate in April, including claims that the status of democracy and the rule of law had deteriorated severely in Hungary; that the disputed laws should be suspended or revoked; that the spending of EU funds should be more strictly controlled. Members of the European Parliament (MEP) requested the EU to initiate Article 7 proceedings and instructed the European Parliament Committee on Civil Liberties, Justice and Home Affairs to prepare a special report for approval by a plenary session.

MEP also called on the Hungarian government to suspend laws enforcing stricter provisions against asylum-seekers and NGOs, and to reach an agreement with the US authorities about the CEU. The report also repeated that the EC should enforce the October 2016 proposal calling on the Commission to bring into force a mandatory inspection mechanism in respect of the situation in member states and to bring out annual reports regarding breach of democracy, violations of fundamental rights and the rule of law.

On 12 September 2018, following lengthy deliberations, the European Parliament approved the report compiled by Dutch MEP Judith Sargentini on the state of the rule of law in Hungary (European Parliament, 2018). The document called on the Council to trigger Article 7 proceedings, i.e. to ascertain that there was a clear risk of Hungary breaching the founding values of the EU, because according to the document - in addition to other issues - the independence of the judiciary, the freedom of speech, the rights of minorities, the situation of migrants and refugees were causes for concern (Köves, 2018). The Hungarian government then used its own communication channels and several GONGOs (Government-Organized Non-Governmental Organisations that are pseudo-NGOs) to dispute the findings of the Report (Alapjogokért Központ, 2018), applying the frequently used strategy which is based on citizen's insecurity perception.

The government response was two pronged: first there was a challenge to the legal standing of the proceedings themselves, and then also cognitive dissonance and chaos were generated through the reinterpretation and laboured explanations of the terms. It was argued that there was no absolute definition of the concept of democracy, and that the rule of law had different meanings due to the different cultural/historical backgrounds of member states. 
While in March 2019 Fidesz decided to voluntarily suspend its membership of the European People's Party, the parent organisation of Fidesz in European Parliament, it was also decided that the Hungarian party would not be kicked out immediately, that the audit would have to be completed. A so-called "Council of Three Wise Men" (consisting of Herman Van Rompuy, Hans-Gert Pöttering and Wolfgang Schüssel) investigated the status of the rule of law and compliance with the conditions of the EPP, reporting back to its chairman, Donald Tusk.

\section{Poland}

\section{5 elections - PiS success and rhetoric}

On 25 October 2015, elections to the Sejm and Senate (lower and upper chambers of parliament) were held in Poland. The right-wing Law and Justice Party (Prawo i Sprawiedliwość, PiS) won the election with just over $37.5 \%$ of the vote ${ }^{7}$. PiS was able (for the first time in the democratic history of Poland) to form a government without the need for seeking allies in other parties that entered Sejm, with full control over the legislature and executive branches of government. President Andrzej Duda (former PiS member who had won the presidential elections just a few months earlier) appointed Beata Szydło (PiS) as the prime minister.

The reasons for the public support received by the PiS victory can be understood in terms of public disenchantment with the economic policy of the previous, liberal government (Civic Platform, Platforma Obywatelska, or PO), which had been caught between ideological compulsions and attempts to soften the blow of the effects of the European financial crisis. The reforms included raising the statutory retirement age and increasing flexibility in respect of labour laws and regulations. Although the macroeconomic situation in Poland looked healthy, there was feeling of no security of employment and social benefits were seen as unsatisfactory.

As in the case of Hungary, the securitization of the migration crisis discourse (Podgórzańska, 2019) also played an important role. At the same time, it is necessary to emphasize the effective use of social media by PiS in highlighting the scandals of the PO government and its liberal policies which were unacceptable by conservative part of society (e.g. regarding in vitro fertilization and minor expansion of the rights of transgender persons (Marcinkiewicz and

\footnotetext{
${ }^{7}$ Formally, the PiS is dominant component of the coalition known as the United Right and include two smaller right wing parties-Solidarna Polska and Porozumienie Jarosława Gowina. Members of three parties were included in the final list of candidates to parliament.
} 
Stegmaier, 2016). Another important factor that influenced the parliamentary success of the United Right was the victory in the presidential election of Andrzej Duda (Wojtasik, 2016).

\section{The PiS government in action}

The United Right government of Beata Szydło (led from behind the scenes by Jarosław Kaczyński) with its parliamentary majority quickly began to introduce many of the deep reforms of state structures and public policies announced in the electoral campaign. The uncompromising nature of the changes introduced led to a polarization between supporters and opponents of the government.

The government described its proposals as the "good change"- a major shift in the paradigm of the functioning of the state. During the earlier brief period when PiS was in power (2005-07), it had used the slogan of "IV Republic" to underline the need to begin a new form of government, without ties to the post-communist regimes. Reasons for public support for PiS were a number of social programs that had been announced and quickly introduced e.g. "Family 500+" introducing a 500-zloty (ca. 120 Euro) family benefit for each second and subsequent child or the possibility of early retirement (60 years for women and 65 for men). The "Apartment + " project was prepared to enable Poles to rent cheaper apartments, with the option of buying them. A regulation on a minimum hourly wage for work performed under civil law contracts was amended and a program enabling persons aged over 75 years to acquire certain drugs free of charge was also introduced.

In the area of education, the government reverted to the traditional age for starting school, which was 7 years. The previous government had lowered the age to 6 . Changes in the core curriculum were introduced, the three-tier school system ended and was replaced by a two-tier model.

In other fields, the government made changes which had far reaching consequences, for example in relation to the media and national security. It created a volunteer Territorial Defence Force as the fifth addition to the Armed Forces; it also increased the powers of the intelligence agencies. It pressurized journalists from public media to leave their jobs and hired others who were ideologically close to the ruling party. It gradually ensured that privately held media companies also became less independent in their broadcasting policies and more favourable to the government. These developments polarized Poles deeply. 
The government tried to make up for the increased expenses with new sources of income. It imposed new taxes, including one commonly known as the banking tax, levied on the assets of financial institutions. Szydło’s government also attempted to "seal the tax system" and began the fight against the "VAT carousel", or fraud in respect of VAT taxes. Actions against "VAT fraudsters" became quite popular with citizens. The government announced a long-term vision for developing the national economic potential, describing it as an "Action plan for responsible development of Poland". Adopted in February 2016, it set out, among other goals, the reindustrialization of the country and making Polish companies more innovative (Ministry of Economic Development, 2016).

The "change of current policy and form of exercising power" announced in Szydło’s government programme also caused a lot of controversy. In institutions of culture, diplomacy and public administration it meant layoffs. This can be seen as a process of "cleaning up the civil service" which had served previous governments.

The United Right government also initiated the "politics of memory" aimed at wiping out any sympathy for the communist system. It passed a law "on the prohibition of propagating communism or other totalitarian regimes through the names of organizational units, auxiliary units of the commune, buildings, public buildings and facilities, and monuments". The idea behind it was to finally rupture the community's links with the so-called post-communist heritage. In practice the enforcement of the law meant a change of street names.

A new prime minister was installed to try to repair Poland's damaged relationship with the EU on the issue of judicial system reforms (Przybylski 2018). However, the controversial changes of the previous United Right government were not withdrawn. Mateusz Morawiecki himself forced further changes in the judicial system.

\section{Article 7 of the TEU against Poland}

After the 2015 elections Poland began to be seen as a country in the midst of democratic backsliding. Due to the newly established right-wing government's changes, Poland has received a great deal of attention in international institutions and media. One of many controversial interventions by the new government was in relation to the judicial system. The laws that brought in changes in the composition and functioning of the Constitutional Tribunal and which seemed designed to curtail the independence of its judges became the first reasons for the European 
Commission to begin action against Poland. Also, the Council of Europe, and particularly its advisory body - The European Commission for Democracy through Law (so called Venice Commission)—-become interested in the situation in Poland ${ }^{8}$.

In December 2015 and January 2016 the Sejm adopted another set of sensitive laws, dealing with the media, the civil service, the Police, and the Public Prosecution Office (European Commission, 2017c). In January 2016 a debate took place in the College of Commissioners, which was followed by the launch of a dialogue and a request for information from the Polish authorities on the situation regarding the rule of law (European Commission, 2017a). First Vice-President Timmermans was mandated by the Commission to enter into a dialogue with the Polish institutions (European Commission, 2017c).

From February to July 2016 both parties exchanged a number of statements and held several meetings. In March 2016, the Venice Commission adopted its opinion "on amendments to the Act of 25 June 2015 on the Constitutional Tribunal" and called for a solution that would respect the judgments of the Constitutional Tribunal (Venice Commission of the Council of Europe, 2017). Simultaneously the European Parliament started a debate on the situation in Poland. On 13 April 2016, the Resolution urging the Polish Government to respect, publish, and fully implement the judgments of the Constitutional Tribunal was voted on. It included the statement that the effective paralysis of the Constitutional Tribunal in Poland posed a danger to democracy, human rights, and the rule of law. The Polish Government was urged to fully implement without further delay the Constitutional Tribunal's judgment of 9 March 2016 and to implement the judgments of 3 and 9 December 2015 (judgements were confirming unconstitutionality of the amendments of the Act on the Constitutional Tribunal) as well as to fully implement the recommendations of the Venice Commission.

In the Resolution it was also stated that the EP supported the Commission's decision to launch "a structured dialogue under the Rule of Law Framework" and referred to the possibility of the activation of the further procedure whereby a "rule of law recommendation" could be issued in case Poland did not comply with the Commission's recommendations (European Parliament, 2016).

\footnotetext{
${ }^{8}$ Venice Commission was invited to visit Poland and to study the reforms by the Polish government itself.
} 
On 1 June 2016 the Commission, not satisfied with the solutions implemented by the Polish Government, adopted the Rule of Law Opinion to the Polish Government. As Timmermans said "There have been constructive talks which should now be translated into concrete steps to resolve the systemic risk to the rule of law in Poland. The Opinion adopted today presents our assessment of the issues at stake, building on the dialogue which started in January [2016-authors]. On this basis we stand ready to continue the dialogue with the Polish authorities." (European Commission, 2016a). The Polish Government was invited to address its concerns within three months.

On July 2016, the Commission adopted a Recommendation according to which Polish authorities (First recommendation) were supposed to act urgently to:

1. "implement fully the judgments of the Constitutional Tribunal of 3 and 9 December 2015 which require that the three judges that were lawfully nominated in October 2015 by the 7th term of the Sejm can take up their judicial functions in the Constitutional Tribunal, and that the three judges nominated by the 8th term of the Sejm to already occupied posts without a valid legal basis do not take up their judicial functions;

2. publish and implement fully the judgments of the Constitutional Tribunal of 9 March 2016 and ensure that the publication of future judgments is automatic and does not depend on any decision of the executive or legislative powers;

3. ensure that any reform of the law on the Constitutional Tribunal respects the judgments of the Constitutional Tribunal, including the judgments of 3 and 9 December 2015 and the judgment of 9 March 2016, and takes the opinion of the Venice Commission fully into account; and ensure that the effectiveness of the Constitutional Tribunal as a guarantor of the Constitution is not undermined by requirements inconsistent with the rule of law;

4. ensure that the Constitutional Tribunal can review the compatibility of the new law adopted on 22 July 2016 on the Constitutional Tribunal before its entry into force and publish and implement fully the judgment of the Tribunal in that respect;

5. refrain from actions and public statements which could undermine the legitimacy and efficiency of the Constitutional Tribunal." (European Commission, 2016b).

Polish representatives responded on the basis of the official statement of disagreement on all the issues raised (MSZ, 2017). 
As there was no satisfactory solution regarding the issues raised in June, the Commission adopted the second Rule of Law Opinion addressed to the Polish Government on 21 December 2016, concluding that there were still unsolved threats to the rule of law in Poland (European Commission, 2016c). Poland again disagreed with the Commission and stated that it did not perceive any threats to the rule of law (MSZ, 2016).

In July 2017 the Commission adopted a third Rule of Law Recommendation. In it the main concerns were repeated and new ones added, such as the unlawful appointment of the President of the Constitutional Tribunal, dismissal of Supreme Court judges, and introduction of the National School of Judiciary. A list of proposed remedies was also included (European Commission, 2017b).

The Rule of Law in Poland had already several times become the subject of debates and hearings in the General Affairs Council of the EU. In April the Commission also decided to launch an infringement procedure against Poland (European Commission, 2019).

Likewise, the Council of Europe is concerned about the rule of law in Poland. On 23 January 2020, the Parliamentary Assembly of the Council adopted a resolution on the functioning of democratic institutions in Poland stating that the actions of the Polish authorities "cumulatively undermine and severely damage the independence of the judiciary and the rule of law in Poland. Moreover, the reforms have made the judicial system vulnerable to political interference and attempts to bring it under political control of the executive, which challenges the very principles of a democratic State governed by the rule of law" (Council of Europe, 2020).

The Council of Europe underlined the excessive centralization of powers over the judiciary and curtailment of the independence of the prosecution service; it also referred to the way the government had ignored decisions of the Constitutional Tribunal. The changes which were particularly pointed out as threats to the rule of law in Poland were:

- $\quad$ ad personam merger of the posts of Minister of Justice and Prosecutor General ("the extensive discretionary powers over the prosecution service and the actual prosecution of individual cases itself given to the Minster of Justice, undermine the impartiality and independence of the Prosecution Service and make it vulnerable to politicisation and abuse").

- changes in the structure of the National Council of the Judiciary (15 judges are no longer elected by their peers but by the Polish parliament — "this runs counter to the principle of 
separation of powers and the independence of the judiciary. As a result, the National Council of the Judiciary can no longer be seen as an independent self-governing body of the judiciary").

- the appointment and dismissal of court presidents by the Ministry of Justice, disciplinary proceedings against judges and the internal organisation of the courts ("this is compounded by the equally excessive powers given to the Minister as Prosecutor General and the absence of a counterbalance by a genuinely independent National Council of the Judiciary").

- Changes in the Supreme Court (early retirement - " "the composition, and manner of appointment, of the members of the disciplinary and extraordinary appeals chambers of the Supreme Court, which include lay-members, in combination with extensive powers of these two chambers and the fact that their members were elected by the new National Council of the Judiciary, raise questions about their independence and their vulnerability to politicisation and abuse") (Council of Europe 2020).

Both the EU and the CoE can be seen to have concentrated their focus on the structure of the Polish judiciary. Clearly the growing political control over the judicial system is seen by European organizations as one of the most critical threats to democracy and rule of law.

\section{The Present Situation}

Finally, on 16 January 2020 the European Parliament voted to continue the Article 7 proceedings launched against Poland and Hungary. In total, 446 MEPs voted for the proposal, 178 against; 41 were absent. Most members of the EPP also voted 'yes'. According to the EP position statement, the standing of the rule of law had deteriorated in both countries, and neither member had taken meaningful steps to ensure its re-establishment. The EP requested the Council of the European Union to prepare specific recommendations for the countries to follow, and also to set deadlines by when they had to be complied with. The adopted resolution also suggested that the use of EU funding in the future should be tied to compliance with the rule of law. ${ }^{9}$

9 See: EP-vita: A hetes cikk hatástalan, új eljárás kell. [EP-dispute: Article 7 is inefficient, new procedure is needed] https://index.hu/kulfold/eurologus/2020/01/15/ep_hetes_cikk_elorelepes_hatarozat_magyar_lengyel_fejlemenyek/[accessed 03/02/2020] 


\section{The significance of the EU budget and funds}

The current situation is that the 2021-2027 EU budgeting cycle is still under discussion and given the significance it holds for the functioning of the EU in the near-term future a sense of compromise is in the air. The EU's technocratic leadership has already started to tone down the proposals of political groups urging the implementation of sanctions. The existence of these parallel priorities suggests that the EU is ready to sacrifice the condition regarding the observance of the rule of law in the face of uncertainties related to the EU budget and funds. This is the reality despite the fact that the rule of law is at risk in more and more member states (GostyńskaJakubowska 2020).

\section{Conclusion}

The European Union has been facing a number of challenges over the last two decades and has been unable to give effective answers as a community. Throughout the whole continent there has been a gradual erosion of the belief in democracy and in the efficacy of supranational cooperation, as a result of permanent crises, financial and economic problems and, perhaps most significantly, migration-related challenges. This disenchantment has left the most prominent mark in the Central and Eastern European states, some of the newest members of the EU. In those countries the reaction of the political class to the uncertainties and economic challenges of the period has been to assume that the solution lies in making the nation-state stronger and that the means of consolidating and expanding state power, and their own, would be through the use of populist measures.

Poland and Hungary are significant cases of the erosion of liberal democracy within the EU. According to the Varieties of Democracy report for 2020 both countries belong to the small group of countries that 'have autocratized the most over the last 10 years' (V-Dem Institute, 2020). The goal of the paper was to compare the process of the de-democratization of the two countries from the point of view of the EU allegations. The paper aims to examine the mechanism used to destroy or modify or reshape the liberal democratic framework in Hungary and Poland rather than the reasons for what was done ((the how rather than the why).

Comparison of the process of democratic erosion in both CEE countries reveals a very similar path of de-democratization: (1) crisis in the country leads to the victory of a party which ignites anger against the ruling parties (socialist-liberal in Hungary, centrist in Poland); (2) a 
decisive victory in the elections allows for establishing a one-party government; (3) the government's narration emphasizes the need of a "new quality" of management for the country; (4) infringement of the checks and balances system, supported by the excuse that the government had the people's support, takes on increasing form; (5) the government's key actions are targeted against judicial independence (especially in the context of the constitutional court and councils responsible for nominating judges), public media, truly independent NGOs, the attorney general's office; (6) in both countries the issue of securitization of the immigration policy played an important role in the actions of the Fidesz and PiS.

However, the paper also shows that the EU actions, which were taken when the governments in Poland and Hungary made major changes in the above mentioned areas, concerns mostly the principle of the rule of law. Despite the fact that the process of political changes in both countries follows the Ziblatt and Levitsky's model, the EU, due to issues of procedural possibilities, is able to refer mainly to the threats of the rule of law. Among the values referred to in Article 2 of the TEU, the rule of law issue is underlined in the procedures against Hungary and Poland. Since the paper examines the EU actions in relation to democratic backsliding in the two CEE states from the perspective of political science, rather than the legal, conclusion can be that how could the EU protect liberal democracy mostly when the principle of the rule of law is under attack.

Finally, on 9 October 2020 European Parliament plenary session adopted the resolution on establishing an EU mechanism in order to protect and strengthen democracy underlining that only agree to a long-term budget if there is an opportunity that allows for EU funding to be reduced or suspended if a member state disrespects the rule of law.

Developments in both countries represent significant challenges to the ideology of the EU and its rules. The European Union which is regarded as a body that supports postmodern values should understand the reasons and process of democratic backsliding very well. What needs to be further researched is whether Poland actually modeled its reforms on Fidesz actions in Hungary or whether there is a general pattern of erosion of democracy, which is the same everywhere.

\section{References}

1. ACEMOGLU, D. and ROBINSON, J.A. (2006) Economic Origins of Dictatorship and Democracy. Cambridge: Cambridge University Press, 2006. 
2. ALAPJOGOKÉRT KÖZPONT. (2018) A Sargentini-jelentés TOP10 tévedése, http://alapjogokert.hu/wp-content/uploads/2018/09/A-Sargentini-jelent\%C3\%A9s-top101t\%C3\%A9ved\%C3\%A9se.pdf [accessed 17/01/2020].

3. BALOGH, P. (2017) The revival of 'Central Europe' among Hungarian political elites: its meaning and geopolitical implications., Hungarian Geographical Bulletin, 66(3), pp. 19-202.

4. BOZÓKI, A. and HEGEDÜS, D. (2018) An externally constrained hybrid regime: Hungary in the European Union, Democratization, 25:7, pp. 1173-1189.

5. BRUSZT, L. (2015) Regional Normalization and National Deviations: EU Integration and Transformations in Europe's Eastern Periphery. Global Policy, Vol. 6, No. 1, pp. $38-45$.

6. COUNCIL OF EUROPE. (2020) Resolution 2316 (2020) The functioning of democratic institutions in $\quad$ http://semanticpace.net/tools/pdf.aspx?doc=aHR0cDovL2Fzc2VtYmx5LmNvZS5pbnQvbncveG1sL1hSZWYv WDJILURXLWV4dHIuYXNwP2ZpbGVpZD0yODUwNCZsYW5nPUVO\&xsl=aHR0cDovL3 NlbWFudGljcGFjZS5uZXQvWHNsdC9QZGYvWFJlZi1XRC1BVC1YTUwyUERGLnhzbA== \&xsltparams $=$ ZmlsZWlkPTI4NTA0 [accessed 29/03/2020].

7. CSEHI, R. and ZGUT, E. (2020) 'We won’t let Brussels dictate us': Eurosceptic populism in Hungary and Poland, European Politics and Society. Online publication.

8. DAHLBERG, S., Linde, J. and HOLMBERG, S. (2015) Democratic discontent in old and new democracies: assessing the importance of democratic input and governmental output. Political Studies, 63 (2015), pp. 18-37.

9. DOBSON, W.J. (2013) The Dictator's Learning Curve: Inside the Global Battle for Democracy. Anchor Books, Random House Inc.

10. DRINÓCZI, T. and BIEŃ-KACAŁA, A. (2019) Extra-legal particularities and illiberal constitutionalism - The case of Hungary and Poland. Hungarian Journal of Legal Studies 59, No 4, pp. 338-354.

11. EURACTIV. (2017) "EU opens sanctions procedure against Hungary, Poland and Czech Republic over refugees", Euractiv, 13/06/2017, http://www.euractiv.com/section/justicehome-affairs/news/eu-opens-sanctions-procedure-against-hungary-poland-and-czech-republicover-refugees/ [accessed 01/12/2017]. 
12. EUROPEAN COMMISSION. (2014) Communication from the Commission to the European Parliament and the Council, A new EU Framework to strengthen the Rule of Law, https://eur-lex.europa.eu/legal-content/EN/TXT/PDF/?uri=CELEX:52014DC0158\&from=EN [accessed 29/03/2020].

13. EUROPEAN COMMISSION. (2016a) Commission Adopts Rule Of Law Opinion On The Situation In Poland. https://ec.europa.eu/commission/presscorner/detail/en/IP_16_2015 [accessed 29/03/2020].

14. EUROPEAN COMMISSION. (2016b) Commission Recommendation (EU) 2016/1374 of 27 July 2016 regarding the rule of law in Poland (2016) Official Journal of the European Union L217/53

15. EUROPEAN COMMISSION. (2016c) COMMISSION RECOMMENDATION of 21.12.2016 regarding the rule of law in Poland complementary to Commission Recommendation (EU) 2016/1374, Brussels, 21.12.2016, C(2016) 8950 final.

16. EUROPEAN COMMISSION. (2017a) Commission Action On The Rule Of Law In Poland: $\quad$ Questions $\quad \& \quad$ Answers, https://ec.europa.eu/commission/presscorner/detail/en/MEMO_17_5368 [accessed 29/03/2020].

17. EUROPEAN COMMISSION. (2017b) Commission Recommendation (EU) 2017/1520 of 26 July 2017 regarding the rule of law in Poland complementary to Recommendations (EU) 2016/1374 and (EU) 2017/146 C/2017/5320, OJ L 228, 2.9.2017, p. 1932, https://eur-lex.europa.eu/legal-content/EN/TXT/?uri=CELEX\%3A32017H1520

18. EUROPEAN COMMISSION. (2017c) Reasoned Proposal in Accordance With Article 7(1) of the Treaty On European Union Regarding the Rule Of Law in Poland, Proposal for a COUNCIL DECISION on the determination of a clear risk of a serious breach by the Republic of Poland of the rule of law Brussels, 20.12.2017, COM(2017) 835 final, 2017/0360 (APP).

19. EUROPEAN COMMISSION. (2019). Rule of Law: European Commission launches infringement procedure to protect judges in Poland from political control. https://ec.europa.eu/commission/presscorner/detail/en/IP_19_1957 [accessed 29/03/2020].

20. EUROPEAN PARLIAMENT. (2016). European Parliament resolution of 13 April 2016 on the situation in Poland (2015/3031(RSP)), https://www.europarl.europa.eu/doceo/document/TA-8-2016-0123 EN.html [accessed 29/03/2020]. 
21. EUROPEAN PARLIAMENT. (2017) Vita Magyarországról Orbán Viktor Miniszterelnökkel, https://www.europarl.europa.eu/news/hu/pressroom/20170424IPR72035/vita-magyarorszagrol-orban-viktor-miniszterelnokkel [accessed 03/02/2019].

22. EUROPEAN PARLIAMENT. (2018). A Jogállamiság Helyzete A Tagállamokban És A Híres 7. Cikk, https://www.europarl.europa.eu/news/hu/headlines/euaffairs/20180222STO98434/a-jogallamisag-helyzete-a-tagallamokban-es-a-hires-7-cikk [accessed 11/02/2020].

23. EUROPEAN PARLIAMENT. (2020). Rule Of Law In Poland And Hungary Has Worsened https://www.europarl.europa.eu/news/en/press-room/20200109IPR69907/rule-of-lawin-poland-and-hungary-has-worsened [accessed 30/01/2020].

24. GLIED, V. (2014) From the Green movement into a party. Effect of the crisis and democratic movements in Hungary, Politeja nr 28/2014, pp. 31-61.

25. GLIED, V., and PAP, N. (2016) The 'Christian Fortress of Hungary': The Anatomy of the Migration Crisis in Hungary, in B. Góralczyk (Ed.), Yearbook of Polish European Studies 2016. University of Warsaw, Warsaw.

26. GOSTYŃSKA-JAKUBOWSKA, A. (2020) Make no mistake: Poland and Hungary are not the only EU states abusing the law. $22 \quad 012020$. https://www.theguardian.com/commentisfree/2020/jan/22/poland-hungary-eu-states-abusing-law [accessed 11/02/2020].

27. GOTEV, G. (2016) Orbán will tour EU capitals with 'Schengen 2.0' plan, Euractiv, 18/04/2016, http://www.euractiv.com/section/justice-home-affairs/news/orban-will-tour-eucapitals-with-schengen-2-0-plan/ [accessed 1/12/2017].

28. GRIFFIN, J.D. and de JONGE, C.K. (2014) Income inequality, citizen polarization, and political protest. Boulder: University of Colorado.

29. HERMANN, R. (2015) Endstation Islamischer Staat?: Staatsversagen und Religionskrieg in der arabischen Welt, dtv Verlagsgesellschaft.

30. JAKAB, A. (2018) Miért nem müködik jól a magyar jogrend és hogyan javíthatjuk meg? MTA Law Working Papers. MTA TK JTI, Budapest, 2018/01.

31. JUHÁSZ, A., LÁSZLÓ R., and ZGUT E. (2015) Egy illiberális vízió eddigi következményei. Friedrich Ebert Stiftung-Political Capital, Budapest. 
32. JUSTINO, P. and MARTORANO, B. (2016) Inequality, Distributive Beliefs and Protests: A Recent Story from Latin America, HCiN Working Paper 218, May 2016.

33. KACZIBA, P. (2020) Political Sources of Hungarian Soft Power, Politics in Central Europe, Vol.15, 1S (2020), pp. 81-111.

34. KELEMEN, K. (2017) The New Hungarian Constitution: Critiques from Europe. In: Review of Central and East European Law, pp. 1-49.

35. KORONCAI, A. (2014) Orbán és a lehetetlen művészete. Méltányosság Politikaelemző

Központ. http://meltanyossag.hu/content/files/Orb\%C3\%A1n\%20\%C3\%A9s\%20a\%20lehetetlen\%20m\% C5\%B1v\%C3\%A9szete.pdf_[accessed 29/03/2020].

36. KÖRÖSÉNYI, A. and PATKÓS, V. (2015) Liberális és illiberális populizmusBerlusconi és Orbán politikai vezetése. Politikatudományi Szemle XXIV/2. pp. 29-54.

37. KÖVES, N. (2018). The Sargentini Report - Its Background And What It Means For Hungary And For The EU, https://www.boell.de/en/2018/09/19/sargentini-report-itsbackground-and-what-it-means-hungary-and-eu [accessed 6/02/2020].

38. LEVITSKY, S. and WAY, L. (2010) Competitive Authoritarianism: Hybrid Regimes after the Cold War. Cambridge: Cambridge University Press.

39. MARCINKIEWICZ, Kamil \& STEGMAIER, Mary. (2016). The parliamentary election in Poland, October 2015. Electoral Studies, vol 41, pp. 221-224.

40. MIHÁLYI, P.: Mérlegen a rendszerváltás 25 éve. Közgazdasági Szemle, LXI. évf., 2014. július-augusztus (898-922. o.)

41. MINISTRY OF ECONOMIC DEVELOPMENT. (2016). Action Plan For Responsible Development Of Poland. https://www.gov.pl/documents/33377/436740/ResponsibleDevelopmentPlan_pressrelease.pdf [accessed 20/05/2020].

42. MSZ. (2016). Oświadczenie MSZ dotyczące odpowiedzi strony polskiej na uzupełniające zalecenie Komisji Europejskiej z dnia 21 grudnia 2016 roku, https://www.msz.gov.pl/pl/aktualnosci/wiadomosci/oswiadczenie_msz_dotyczace_odpowiedzi_s trony_polskiej_na_uzupelniajace_zalecenie_komisji_europejskiej_z_dnia_21_grudnia_2016_rok u;jsessionid=F5711FD78C64C717FDBAD59F29E1804B.cmsap6p [accessed 29/03/2020]. 
43. MSZ. (2017). Stanowisko strony polskiej na Zalecenie uzupełniające Komisji $\begin{array}{llllllll}\text { Europejskiej w sprawie praworządności w Polsce } & \text { z } & 26 & \text { lipca } & 2017 & \text { r., }\end{array}$ https://for.org.pl/upload/Media/StanowiskostronypolskiejnaZalecenieuzupeniajceKEwspraworza dnosciwPL260717.pdf [accessed 29/03.2020].

44. NATIONAL CONSULTATION.

https://www.kormany.hu/download/d/1d/01000/Nemzeti\%20Konzult\%C3\%A1ci\%C3\%B3.pdf [accessed 25/12/2018].

45. NORRIS, P. and INGLEHART, R. (2019) Cultural Backlash: Trump, Brexit, and Authoritarian Populism, Cambridge: Cambridge University Press.

46. O'DONNELL, G.A. (1998) Horizontal accountability in new democracies. In: Journal of Democracy 9.3 (1998), pp. 112-126.

47. PALONEN, E. (2018) Performing the nation: the Janus-faced populist foundations of illiberalism in Hungary, Journal of Contemporary European Studies, 26:3, pp. 308-321.

48. Polt Péter Kinevezése óta meredeken zuhan a politikai korrupciós ügyekben indított eljárások száma. (2015), http://atlatszo.hu/2015/02/06/polt-peter-kinevezese-ota-meredekenzuhan-a-politikai-korrupciosugyekben-inditott-buntetoeljarasok-szama [accessed 29/03/2020].

49. PODGÓRZAŃSKA, R. (2019). The Issue of Securitization of the Refugee. Polish Political Science Yearbook. 48, pp. 67-89.

50. RUPNIK, J. (2016) Surging Illiberalism in the East. Journal of Democracy, Vol. 27, No. 4, pp. 77-87.

51. SADURSKI, W. (2018) How Democracy Dies (in Poland): A Case Study of AntiConstitutional Populist Backsliding, Legal Studies Research Paper No. 18/01, January 2018.

52. SÁRKÖZY, T. (2014) Kétharmados túlzáskormányzás - avagy gólerős csatár a mély talajú pályán. Park Kiadó, Budapest.

53. SATA, R. and KAROLEWSKI, I.P. (2019) Caesarean politics in Hungary and Poland. East European Politics. Routledge, Taylor and Francis.

54. SCHMIDT, A. (2018) Challenges of the Illiberal Democracy in Hungary. Some Aspects to the 2018 Elections. Polish Political Science Review / Polski Przeglad Politologiczny 6:2, pp. 70-90.

55. SZABÓ, Zs. (2017) Orbán beszólt Macronnak, [Orbán teases Macron], Napi.hu, 22/06/2017, 
http://www.napi.hu/magyar_gazdasag/orban_beszolt_macronnak_videoval_.642203.html [accessed 1/12/2017].

56. TÖLGYESSY, P.: Kompország reményei. (2017) In: Jakab András - Urbán László (szerk.): Hegymenet - Társadalmi és politikai kihívások Magyarországon. Osiris Kiadó, Budapest,.

57. PRZYBYLSKI, W. (2018) Explaining Eastern Europe: Can Poland's Backsliding Be Stopped?, Journal of Democracy, July 2018, Volume 29, Issue 3.

58. REFERENDUM.

http://kormany.hu.

2016 http://nepszavazas2016.kormany.hu [accessed 01/01/2017].

59. V-DEM INSTITUTE. (2020) Autocratization Surges-Resistance Grows DEMOCRACY REPORT 2020, https:/www.v-dem.net/media/filer_public/f0/5d/f05d46d8-626f4b20-8e4e-53d4b134bfcb/democracy_report_2020_low.pdf_[accessed 29/03/2020].

60. VENICE COMMISSION OF THE COUNCIL OF EUROPE. (2017) Annual $\begin{array}{llll}\text { Report } & \text { Of } & \text { Activities }\end{array}$ https://www.venice.coe.int/webforms/documents/default.aspx?pdffile=CDL-RA(2016)001-e [accessed 29/03/2020].

61. WOJTASIK, W. (2016) Parliamentary elections 2015 in Poland: trends and tactics, https://pl.boell.org/en/2016/02/12/parliamentary-elections-2015-poland-trends-and-tactics [accessed 29/03/2020].

62. ZAKARIA, F. (1997) The Rise of Illiberal Democracy. Foreign Affairs, 76(6), pp. 22-43.

63. KERNER, Zs. (2019) Soros: A CEU Megvédte az akadémiai szabadságot Orbán Viktor korrupt kormányától, https://24.hu/kulfold/2019/11/15/soros-a-ceu-megvedte-azakademiai-szabadsagot-orban-viktor-korrupt-kormanyatol [accessed 31/01/2020]. 